\title{
Native-speakerism and professional teacher identity in L2 pronunciation learning
}

\author{
Sharif Alghazo and Mahmoud Zidan \\ Department of English Language and Literature, Faculty of Foreign Languages, The University of Jordan, \\ Amman 11942, Jordan
}

\begin{tabular}{|c|}
\hline $\begin{array}{l}\text { ABSTRACT } \\
\text { Many studies in different contexts have examined both English as a second language (ESL) and } \\
\text { English as a foreign language (EFL) students' convictions about the connection between } \\
\text { nativeness in English and professional teacher identity; however, very few studies solely focused } \\
\text { on that connection in second language (L2) pronunciation teaching. This paper explores EFL } \\
\text { university students' experiences in learning English pronunciation from 'native'-and 'nonnative'- } \\
\text { English-speaking teachers (NESTs and NNESTs). Based on an empirical study of } \\
\text { undergraduates - prospective English language teachers-at the University of Jordan, the paper } \\
\text { finds that most students still view 'nativeness' as the main descriptor of effective teaching, } \\
\text { strongly believing NESTs to be the 'authority' and source of 'correctness,' both of which } \\
\text { convictions are emblematic of native-speakerism, which in turns leads to both cultural panic and } \\
\text { voicelessness on the part of NNESTs and learners. The study concludes with calling for the need } \\
\text { to raise awareness among EFL students of the various manifestations of English as a global } \\
\text { language - particularly the irrelevance of nativeness to effective teaching-and incorporating } \\
\text { NNESTs into teaching L2 pronunciation and rejecting their marginalisation in teaching } \\
\text { pronunciation in EFL contexts. }\end{array}$ \\
\hline $\begin{array}{l}\text { Keywords: Cultural panic; English pronunciation instruction; native-speakerism; NESTs; } \\
\text { NNESTs; voicelessness }\end{array}$ \\
\hline $\begin{array}{l}\text { First Received: } \\
\text { 6 September } 2018\end{array}$ \\
\hline $\begin{array}{l}\text { Final Proof Received: } \\
24 \text { May } 2019\end{array}$ \\
\hline $\begin{array}{l}\text { How to cite (in APA style): } \\
\text { Alghazo, S., \& Zidan, M. (2019). Native-speakerism and professional teacher ider } \\
\text { pronunciation instruction. Indonesian Journal of Applied Linguistics, 9, } 241 \\
\text { 10.17509/ijal.v9i1.12873 }\end{array}$ \\
\hline
\end{tabular}

\section{INTRODUCTION}

The issue of teachers' identities vis-à-vis 'nativeness' with respect to English as well as its potential ramifications on the English language teaching (ELT) profession has been widely discussed and debated in ELT and Applied Linguistics. The English Today debate between Kachru (1991) and Quirk (1990) is one notable example (see Jenkins, 2006). Traditional arguments in ELT (e.g., Quirk, 1990) were in favour of considering NESTs the only reliable models for L2 learners worldwide, especially in relation to pronunciation learning. These arguments, Braine (2010) argues, may have been popularized in the 1960s and "bolstered by Chomsky's (1965) notions that the 'native'speaker is the authority on language and that he/she is the ideal informant" (p. 3). Such views imply the underestimation of the role of NNESTs (or local English language teachers, as Ma (2012) calls them) in L2 classrooms and their sometimes-implicit exclusion from L2 education. Braine (2010) remarks that the acceptance of that traditional view - that NESTs are the only models for L2 learners-by scholars and teachers prior to the 1990 s could be a result of the belief that raising the issue openly was regarded as "unusually sensitive and...politically incorrect" (p. 2), especially

\footnotetext{
* Corresponding Author

Email: alghazo.sharif@yahoo.com
} 
because scholars in Applied Linguistics tried to avoid politicizing the field.

The current situation, however, is no different from that over two decades ago. Ma (2012), for example, cogently argues that despite the invalidity of the claim that NESTs are linguistic models to be emulated, NESTs still "enjoy a privileged and dominant position" (p. 280) in the teaching profession on the basis of nativeness, while NNESTs are "discriminated against in hiring practices" (p. 281; see also Golombek \& Jordan, 2005, p. 517). As Watson-Todd and Pojanapunya (2009) point out, this discrimination is evident in many EFL contexts in which the credibility of language schools is thought to hinge on the act of hiring expatriate NESTs to teach English language courses. This practice, Medgyes (2001, p. 433) explains, manifests itself in the fact that in certain EFL contexts "even backpackers with no teaching qualifications or teaching experience are extended a warm welcome" (italics added).

These attitudes and practices are examples of what is generally referred to as native-speakerism, "an ideology that upholds the idea that so-called 'native speakers' are the best models and teachers of English because they represent a 'Western culture' from which spring the ideals both of English and of the methodology for teaching it" (Holliday, 2017, p. 1). The prevalence of this ideology has spurred NNESTs all over the world to speak out on their concerns and announce their capacities to teach English effectively. Mainstream literature now accommodates NNESTs' and NESTs' voices that counter the biased, unjustified perceived superiority of NESTs (e.g., Liu, 1999; Mahboob, 2004). For instance, Rampton (1990), who is an NEST himself, espouses NNESTs' arguments and asserts that "expertise" rather than nativeness in the language should be the criterion for effective teaching. Nevertheless, very few studies tackle native-speakerism in the field of L2 pronunciation teaching. This study attempts to help fill that lacuna.

\section{Professional teacher identity}

Associating the identities of English language teachers with nativeness is a position that is becoming more and more defunct (e.g., Rampton, 1990; Holliday, 2015) in light of the current transnational use of English. One of the main underlying problems of this association is the lack of both a critical examination of the global newlyestablished role of English and the criteria for defining 'native-likeness' (Benke \& Medgyes, 2005). In lieu of 'native-likeness' as an indicator of teachers' professional identities, Swan (2015) argues that the "features which do not involve native-speakerism but which emerge from professional beliefs about their teaching, understanding their students' needs and understanding the role of English in their contexts" could be the basis for the creation of new criteria ( $p$. 59). Before we develop these features, we investigate the typical images of both NESTs and NNESTs.

\section{Comparing characteristics of NESTs: Perceived pros and cons}

NESTs are generally characterised as having the natural capacity of producing language spontaneously. Mcneill (2005) explains that their intuitions about the English language enable them to produce "correct, idiomatic utterances" (p. 107) and to evaluate the 'acceptability' of others' linguistic productions - at least, against the variety(ies) which they speak and/or with which they are familiar. This "insider knowledge about 'their' language", Davies (2003) argues, renders NESTs 'sources' to which "we appeal...for the 'truth' about the language" (p. 1). These perceptions of NESTs are most clear in the context of teaching L2 speaking and pronunciation.

However, researchers have outlined a number of deficits that NESTs may have. One main deficit could be NESTs' provision of inauthentic communicative situations. Ferguson (1971) developed the term "foreigner-talk" to describe 'native'-speaker modifications of their speech when communicating with 'nonnative' speakers. Ellis (2012) argues that NESTswhen teaching L2 learners-were found to use "a special register known as "foreigner-talk" which is "characterized by a number of 'modifications' ... [that] affect all levels of language - pronunciation, lexis, grammar and discourse" (p. 116; italics added). In addition, Benke and Medgyes (2005) found that L2 learners, especially those with low proficiency levelswho sometimes form a majority in many EFL contexts - find it difficult to understand NESTs' language either because of their unfamiliarity with NESTs' accents or because of the fast speech rate that characterises most NESTs' talk.

Further, NESTs are sometimes criticised for being monolingual and monocultural, as they present a "linguistic [and cultural] distance" (Mcneill, 2005, p. 107) from L2 learners' linguistic and cultural backgrounds. NESTs acquire their L1 and rarely experience the process of learning an L2, a condition which denies them the ability to "pinpoint those linguistic and non-linguistic issues that can become too high a hurdle for their students to overcome" (Lasagabaster \& Manuel-Sierra, 2005, p. 218). This disadvantage on the part of NESTs is likely to deprive them of the benefit of engaging more closely with L2 learners' immediate or local contexts and makes it difficult for them to draw on learners' sociocultural and contextual experiences in facilitating L2 learning.

On the other hand, NNESTs are perceived by their students to have an excellent ability to teach L2 grammar (e.g., Tatar \& Yildiz, 2010), an area perceived to be difficult for NESTs to teach (e.g., Kamhi-Stein, Aagard, Ching, Paik, \& Sasser, 2004). NNESTs, particularly those who teach in their EFL contexts, are also characterised as having the advantage of sharing with their students a common language which they can use when appropriate while teaching the L2. Many scholars and researchers have argued for the value of bilingual teaching. In his empirical examination of 
bilingual teaching practices in the EFL context of Thailand, Forman $(2007,2010)$ found that the use of the L1 has a positive role in L2 education (see also BrooksLewis, 2009).

Furthermore, NNESTs are also thought to have the advantage of having experienced learning the L2 themselves, a privilege that makes them more cognizant than NESTs of more strategies that might enable their students to develop L2 competence. This experience also allows NNESTs to better understand their students' expectations and to help them set reasonable and achievable goals in their quests for L2 learning. According to Medgyes (1994), NNESTs generally have the ability to

provide a good learner model for imitation, teach language learning strategies effectively, supply learners with more information about the English language, anticipate and prevent learning difficulties better, be more empathic to the needs and problems of learners, [and] make use of the learners' mother tongue. (p. 51)

These abilities help learners become prepared for the job market, especially in contents where English is used as a Lingua Franca (ELF), in which case NNESTs might not benefit learners as much, as they will not have to communicate with NS's (Andrews, 2007, pp. 154-155).

However, NNESTs are sometimes criticised for lacking the confidence and phonological training to teach L2 pronunciation classes as NESTs do. KamhiStein et al. (2004), for example, found that NNESTs self-rated L2 pronunciation as their lowest skills area (see also Alghazo, 2013). Nonetheless, and as far as EFL learners' goals of learning English are concerned, NNESTs may be better qualified to achieve satisfactory levels of intelligibility for their students. Alghazo (2015), for example, found some support for NNESTs by Saudi EFL learners of English in the area of pronunciation teaching. It is obvious that approaches to teaching English in general and speaking as well as pronunciation in particular that are modelled on the 'native'speaker are both limiting and unrealistic. Other criteria are accordingly in order.

\section{Criteria for teaching English}

It can then be noticed that - against a long tradition of idealizing NESTs, particularly in teaching pronunciation-being a 'native'speaker does not necessarily lead to successful teaching and that one cannot confidently assume the superiority of any type of teachers over the other. NESTs should not be considered to be ideal teachers because of their inherited language, nor should NNESTs be considered more effective, merely because they form the majority in the ELT profession (Mahboob, 2003). Rather, teachers' expertise and level of "professionalism" should be the main criteria in determining their ability to teach English to L2 learners (Levis, Sonsaat, \& Link, 2017). Levis, Link, Sonsaat, and Barriuso (2016) found that "instruction on pronunciation skills is more dependent on knowledgeable teaching practices than on native pronunciation of the teacher", a finding which "offer[s] encouragement to non-native teachers in teaching pronunciation" (p. 1). As Rampton (1990, p. 98) argues, educationalists "should speak of accomplished users as experts rather than as native speakers" (italics in original). Rampton (1990) substitutes 'expertise', 'inheritance', and 'alliance' for such terms as 'native speaker' and 'mother tongue' (see also Leung, Harris \& Rampton, 1997).

\section{Filling the gap}

Very few studies solely focus on native-speakerism in the context of teaching L2 pronunciation. In their empirical study of Hungarian learners of English perspectives, Benke and Medgyes (2005) found that NESTs were perceived by students as having the ability to effectively teach oral communication skills, especially in conversation and pronunciation classes, primarily because they "serve as perfect models for imitation" (p. 207). A similar preference for NESTs in the areas of speaking and pronunciation was reported by Watson-Todd and Pojanapunya (2009) among Thai learners of English. In the Arabic context, Buckingham (2014) examined the perceptions of Omani L2 learners of English towards NESTs and NNESTs and found that students professed a clear preference for NESTs as pronunciation models. This widely-entrenched belief among students that NESTs are superior in speaking and pronunciation instruction was also found to be the view of many NNESTs. Tang (1997) conducted a study in which she explored the perceptions of 47 NNESTs towards proficiency and competency of both NESTs and NNESTs and found that all respondents believed in the superiority of NESTs in speaking courses and a majority (92\%) in pronunciation ones (see also Alghazo, 2013). However, in light of current developments in the unrivalled use of English as a lingua franca (ELF) and in scholarly positions as to the irrelevance and unlikelihood of approximating native-speaker accents at the global level, the findings of all the previous five studies imply that the students in the former three studies and the teachers in the latter two may have been unaware of the global role of English and arguments against L2 learners' phonological ultimate attainment (e.g., Moyer, 2013).

Based on the foregoing, it is clear that most previous studies mainly focus on teachers' perspectives towards what constitutes effective English language teachers with very little exploration of the issue from L2 learners' points of view in the context of EFL teaching in the Middle East. It is also clear that, with the exception of Levis et al. (2017), very few studies examined students' convictions about 'native' Englishspeaking pronunciation teachers (NESPTs) vs 'nonnative' English-speaking pronunciation teachers (NNESPTs). As a result, further analyses of students' perceptions of L2 pronunciation teachers are needed. It is this need to which the present study caters. In this paper, the researchers posit that consideration of students' perspectives and preferences is of great significance to confronting native-speakerism. Like 
many other scholars, we affirm that 'nativeness' in English does not guarantee efficacy in L2 education, even - we use the word 'even' to underscore the deepseated connection between beliefs about effective pronunciation teaching and native-speakerism-in L2 pronunciation teaching. More specifically, we argue that given the "sociolinguistic reality" of learners in Jordan and that of English, NESTs are not necessarily the most effective pronunciation teachers to EFL students in general and to Jordanian students in particular. We thus argue that native-speakerism needs to be understood more deeply, and we accordingly develop two terms, cultural panic and voicelessness, to provide a more complex understanding of it.

The present study seeks to answer the following research questions:

1) What are EFL undergraduates' (prospective English language teachers') convictions about NESPTs and NNESPTs?

2) What aspects of their convictions, if any, are underpinned by the discourse of nativespeakerism?

\section{METHOD}

\section{Research design}

The researchers solicited the participation of a group of EFL students ( $\mathrm{N}=112)$ studying Applied English at the University of Jordan-most of whom are prospective English language teachers. The students, registered in four different subjects, were asked for their consent to participate in this research study by filling out a questionnaire and possibly participating in follow-up semi-structured interviews. The researchers explained to them that their participation would not by any means influence the evaluation of their performance, and they were assured that their answers would be confidential and only be used for the purposes of research.

\section{Participants}

Since some students were registered in more than one subject, they were asked to participate only once to avoid repetitive responses. Thus, 100 students (out of 112) voluntarily agreed to take part in the study. Most students were in their 4th year of study (i.e., expecting graduation and potential teaching positions) and had already studied most subjects in this Applied English program. They were also expected to have completed all or most pronunciation-related subjects and be more cognizant of various pedagogical assumptions that would allow them to present conscious answers than those who are newly enrolled. Moreover, they may have taken a course or more on TEFL. Table 1 below presents the demographic information of the participants. It may be noted that the overall number of students who were enrolled in this program at the time of data collection was 551 students. Of these, only 23 were males and 528 females. These numbers may justify the gender imbalance among the participants in this study.

Table 1. Demographic information about participants

\begin{tabular}{|c|c|c|c|c|c|c|c|}
\hline \multicolumn{2}{|c|}{ Gender: \% } & \multicolumn{2}{|c|}{ Age: $\%$} & \multicolumn{2}{|c|}{ Year of Study } & \multicolumn{2}{|c|}{ First Language } \\
\hline Male & $6 \%$ & $18-20$ & $34 \%$ & $2^{\text {nd }}$ & $14 \%$ & Arabic & $98 \%$ \\
\hline Female & $94 \%$ & $21-25$ & $66 \%$ & $\begin{array}{l}3^{\text {rd }} \\
4^{\text {th }}+\end{array}$ & $\begin{array}{l}26 \% \\
60 \%\end{array}$ & English & $2 \%$ \\
\hline
\end{tabular}

\section{Data collection}

A preliminary questionnaire was used as the first method of data collection in the first phase of the study (see Appendix A). It consisted of two main sections: The first collected demographic information about the participants including the age, specialisation, year of study, L1, and gender of each one of them; and the second gauged participants' experiences in learning L2 pronunciation with a special focus on their general convictions about effective L2 pronunciation teachers and their perceptions of NESPTs and NNESPTs. In order to fully understand their entrenched cognitions about the issue at hand, an open-ended question was included to allow students to express their views in regard to the questions raised in the questionnaire more freely.

In the second phase of the study - and based on an initial analysis of students' responses in the questionnaire-focus group (each consisting of 12 students) semi-structured interviews were conducted with 48 students who were selected because they had indicated having had the experience of learning L2 pronunciation from both NESPTs and NNESPTs (see Appendix B for a sample of questions and topics discussed). The interviews were conducted in Arabic to validate and provide a deeper understanding of the questionnaire's quantitative findings. The discussions in the four sessions had been audio-recorded and were later transcribed and translated for analysis. Of the 48 students, 27 actively contributed to the discussion.

\section{Data analysis}

The questionnaire included closed questions and an open one. This necessitated the use of a sequential mixed methods approach (Creswell \& Plano Clark, 2007) in the analysis of data: Data obtained from the closed questions were analysed quantitatively and statistically presented, and data obtained from the open question were qualitatively analysed and consequently thematised to allow for better interpretation and presentation. After interview data were transcribed, they were translated into English. Translated extractswhich were peer-authenticated-were later codified and thematised for presentation. In the analysis of qualitative data, we followed Richards' (2005) approach, in which data are processed through three levels of coding: descriptive, topical, and analytical. 


\section{FINDINGS}

\section{Questionnaire data}

The first question in the questionnaire asked about the participants' prior pronunciation learning experiences. Results indicated that the majority had already studied all/most pronunciation-related subjects. It bears mentioning that there are three pronunciation-related subjects included in the study plan of the program, a fact which entails that the participants had had enough experience to answer the questions and might have learned from both NESPTs and NNESPTs. Responses to the second question showed that almost half the participants had had the experience of learning from both NESPTs and NNESPTs (and those were selected for the focus group semi-structured interviews held afterwards). As for Question 3 which asked about students' preferences for the identity of pronunciation teachers, responses showed that more students preferred NESPTs to NNESPTs, but the majority did not mind the identity of the teacher, as shown in Table 2 below.

Table 2. Students' responses to Questions 1,2 \& 3

\begin{tabular}{llcc}
\hline Question 1 & How many pronunciation subjects had you studied before this semester? \\
\hline Options & 1 Subject & 2 Subjects & 3 Subjects \\
Percentages & $13 \%$ & $49 \%$ & $38 \%$ \\
Question 2 & Have you been taught that/those subject/s by (an) & Both \\
Options & NESPT & NNESPT & $48 \%$ \\
Percentages & $12 \%$ & $40 \%$ & \\
Question 3 & Who do you prefer to learn English pronunciation from? & NNESPT \\
Options & NESPT & $25 \%$ & $48 \%$ \\
Percentages & $27 \%$ & & \\
\hline
\end{tabular}

The fourth question was an open-ended one and asked participants to explain their answers to the third one. Almost all students who preferred NESPTs reported that learning a 'native'accent was the predominant justification for their preference. Believing very strongly in 'correctness' as only coming from NESPTs, students had what we might call an entrenched ideological assumption about 'native' 'accents'. One student whose answer is representative noted that she had found NESPTs helpful "[b]ecause nothing is better than learning English pronunciation from a native speaker-you get the correct pronunciation, and you become familiar with it" (S4; italics added). In addition, those who preferred NESPTs focused on three main perceived disadvantages of NNESPTs: the use of Arabic in teaching L2 pronunciation, the teaching approach that involved "imitation and memorization" (S2), and lack of realism (i.e. students felts that NNESPTs did not present authentic content).

Those who preferred NNESPTs thought that NNESPTs are familiar with students' L1 and thereby able to help them overcome the pronunciation problems that are mainly caused by 'interference'. Others highlighted NNESPTs' presumably more intelligible speech and their having had similar learning experiences to students' before becoming teachers. The students $(48 \%)$ whose responses were of most interest to the researchers were those who did not have any particular preference. Their choices made it incumbent on the researchers to explore these students' responses more fully in the form of focus group interviews.

\section{Interview data}

This section reports the findings obtained from the focus group semi-structured interviews held with the 48 students who had had the experience of learning from both NESPTs and NNESPTs. As noted earlier, of the 48 students, 27-each of whom is assigned a number according to the sequence of their utterance-actively contributed to the discussion and their responses are analysed here. Students' responses indicate more complex thoughts than those mentioned in the questionnaire concerning NESPTs, as they seemed to internalize the discourse of native-speakerism despite their initial claims.

Many students thought highly of NESPTs, primarily because of the perceptions that students have of them, their teaching styles and their accent(s). They considered NESPTs as models or standards, so they wanted to speak like them. S20 suggests that "[t]he NESPT was better than the NNESPT because of her accent." S21 uses clearer terms: "NESPTs are better than NNESPTs because English is their own language, and it is impossible that they make mistakes in pronunciation as NNESPTs do." S23 uses another model: the dictionary, which typically represents the 'standard' native speaker's accent. She claims, "I think the best reference for us may be the dictionary where we can find the most appropriate pronunciation of utterances." It is clear that these students imply that NESPTs are perfect embodiments of the language, even if that embodiment is abstract, as in a dictionary. All of the above indicate a level of cultural disbelief and voicelessness.

Others preferred NESPTs because of their teaching styles and approaches. Many felt that NESPTs encouraged students to be more confident although S5 reports that the teacher's insistence on confidence was unrealistic and counterproductive: "that she wasn't an Arab, so when we, for example, had to give a presentation, she didn't know that we get anxious because we speak a second language." S26 claims, "The NESPT focused on our speech as a whole but not on single words or sounds as the NNESPT did" (S26). According to these students, NESPTs provided delayed feedback (S8), and their approach was holistic, rather 
than detail-oriented. Their focus was on fluency instead of accuracy.

Other students commented on the idea that NESPTs provided them with exposure to accents that they wanted to learn; for them, NESPTs represented desire fulfilment. S1 reported that accent was the only linguistic aspect that she wanted to learn from a 'native'speaker, especially American English. S16 said, "I benefited more from the NESPT because she spoke American English." But even when her NESPT did not speak the variety in which the student was interested, S9 still found NESPTs to be better than NNESPTs (a belief that is widely held among the population of this study and instils cultural panic on the part of NNESPTs):

The NESPT's pronunciation was indeed better than that of the NNESPT, although her accent wasn't the one I wanted to imitate. (Extract 1)

But an NESPT's accent was sometimes a source of confusion according to S6 and S13. S6 says, "What distracts our attention as students is that we learn from different teachers who have different accents: sometimes British and at other times American. We get lost." Likewise, S22 thinks that NESPTs can be a limitation, arguing that NESPTs are monocultural:

The NESPT used to tell us what the appropriate pronunciation of a word is in relation to her own accent only. She was like a model, and we were supposed to imitate her. But the NNESPT would say that your pronunciation may be acceptable in another accent because she knew more about other accents. So the NESPT limited us to the accent she spoke. (Extract 2)

S24 expressed her experience by telling an anecdote: "My NESPT...told me that when she went to America on vacation, Americans looked at her as a person who can't speak English because she wears a hijab." What S24 implies is that some 'native' speakers (or to use "expert speakers," as Rampton (1990) puts it) equate or rather conflate whiteness and ethnicity with linguistic competence, a position that is both myopic and monocultural; indeed, it is inherently racist.

Some students brought to light other limitations. For instance, NESPTs did not show awareness of the problems that students have. S8 thinks that:

The NNESPT was better at dealing with us than the NESPT. She was excellent, and she used to tell us that we, Arabs, have problems with this or that sound/area, and she would focus on it. She knew how Arabs speak in English and how native speakers do, and she was good at identifying our weaknesses. (Extract 3)

Thus, this student (like S5) argues that the lack of NESPTs' culture-specific training was detrimental to her learning.

Meanwhile, NNESPTs' consciousness of students' culture and the problems that they have were strengths worth considering. S6 argues, “[W]e can't say that NESPTs are better than NNESPTs because there are so many NNESPTs who are better-qualified than NESPTs and who are in control of their subjects." Qualification for her does not depend on nativeness. S11 highlights another advantage in her view: "I benefited from the NNESPT more in terms of linguistic knowledge."

Other students reported the opposite experience. For instance, S2, S3, and S26 suggested that NNESPTs focused, as one student put it, on "sounds in isolation". They also claimed that NNESPTs provided immediate feedback, a practice that hindered their learning. S15 suggested another problem that had to do with the teaching style: "The NNESPT made me memorise without much realistic practice, but the NESPT focused on building confidence which would result in better performance." According to this representative response, 'native'speakers provide a path to authenticity.

\section{DISCUSSION}

The first question in this study asked about Jordanian EFL university students' perceptions of NESPTs and NNSPTs. It was evident from the analysis presented above that 'nativeness' is the main criterion for effective teachers of English in general and of English pronunciation in particular according to many students. Some students based their views on the assumption that the 'native'speaker is the only authority and source of correctness. This assumption recalls Chomsky's (1965) notion of the "ideal informant" (Braine, 2010, p. 3), as discussed earlier. Such an assumption may be best interpreted as an evident lack of awareness on the part of students, as such overgeneralizations are-in today's globalised world-out-dated and being a 'native' speaker of the language does not necessarily ensure effective pronunciation teaching (see Levis et al., 2017). However, students even idealized 'native' speakers by describing NESPTs as people who do not make mistakes. It was also shown that most students see NESPTs as models that they want to imitate and the accents they speak as the 'dream' they want to come true. But this attitude is a parochial one. It indicates that despite the existence of evidence that awareness of the status of English, its speakers, and its culture in relation to ELT practices on the part of students in many parts of the world, raising students' awareness needs to be prioritized.

Indeed, aiming at nativeness may also be a psychological detriment to students: Students who believe that they should speak like 'native' speakers will never attempt to speak unless they are certain that their speech is native-like, and this precondition is likely to deprive them of the benefit of practice. More concretely, Golombek and Jordan (2005) write, "Sounding like a native speaker is neither possible nor desirable" (pp. 513-514; italics in original). Moreover, following only one model prevents students from exposure to other varieties of English. Goodwin (2014) rightly asserts, "Since no one accent is dominant in every context, neither teachers nor learners need to sound like idealized native speakers" (p. 145). As Jenkins (2006) has eloquently put it, "Pronunciation [should be] approached from a variety of WEs [World Englishes] 
and ELF perspectives rather than, as is more often the case, as an isolated feature of second (L2) English acquisition whose only desirable endpoint is a so-called native-like accent" (p. 158).

Answers to the second research question, which focused on the connection between students' convictions about the merits and deficits of NESPTs and NNESPTs in L2 pronunciation instruction and nativespeakerism, confirm that the majority of students do espouse this ideology. Students in this study greatly valued NESPTs' accents as the main merit, explicitly noting that this makes them better teachers than NNESPTs. To be sure, no one can deny NESPTs their intuition about English, but it is offensive and racist to discredit other aspects of professionalism and expertise in teaching so much so that an NESPT's accent becomes "like a linguistic albatross around the necks of the users of the language" (Kachru, 1997, p. 9). Medgyes (1994) writes that NNESTs internalize this "linguistic albatross" that pinpoints their "linguistic handicap" and asserts that the existence of such an albatross intimates that the "handicap" can only be overcome by "long stays in English-speaking countries, hard work and dedication...to narrow the gap between 'us' and 'them', but very few of us will ever be able to catch up. To achieve native-like proficiency is wishful thinking" (p. 33). Brown (2007) succinctly explains that "[m]ost of the evidence indicates that persons beyond the age of puberty do not acquire ... authentic (nativespeaker) pronunciation of the second language" (p. 62; bold in original). Indeed, as Ur (2012) argues, NNESTs can be better teachers for international students whose task is not to communicate directly with 'native'speakers, a situation applicable to the majority of students in Jordan.

Students' native-speakerism also surfaced when they reflected on NESPTs' approaches to teaching English pronunciation: Their approach was characterised as being fluency-based as compared to an NNESPTs' accuracy-based approach as reported by students. While fluency is indeed an aspect that should be maintained and aimed at in teaching approaches, particularly in speaking courses, it should be remembered that there is no fluency without accuracy (Nunan, 2015). Ur (2012) explicitly makes the point that fluency and accuracy should evenly be focused on in L2 classes but warns against sticking to native-speaker conventions in the teachers' focus and argues that the conventions should be "those which are used by the majority of fluent, educated speakers of the language in international communication" (p. 1).

In addition to fluency, students appreciated NESPTs' reported emphasis on confidence. Many believed that students' speaking English confidently is a sign of improvement. However, building confidence is a far more complex issue. Golombek and Jordan (2005) use the term "learner agency" (p. 515) to discuss the effects of helping students become more confident. But they warn that "even if an L2 speaker feels confident in her language abilities, native speakers can — and may- still refuse to ratify her as a legitimate speaker" (p. 520). The threat of the lack of "ratification" entails, as a consequence, the constant accumulation of the "nonnative speaker burden" in any communicative situation.

Another problem that ensues is that this overemphasis on confidence privileges the discourse of individuality (see Holliday, 2017, p. 1) and neglects the fact that learning any language involves also the group (see Jenkins, 2006, p. 167). The complexity grows if we take NNESTs' level of confidence into consideration. Levis et al. (2016) state that "NNESTs are regularly reported to lack confidence in their ability to be a good model" (p. 23). By way of illustration, they write, "[I]dentifiable errors in an NNEST's spoken language may change a learner's confidence in the teacher as a reliable model" (p. 24). NNESTs become as a result objects of vulnerability in their students' eyes. We call this phenomenon NNESPTs' 'linguistic panic'. This linguistic panic, one of its main causes being nativespeakerism, produces what we call voicelessness on the part of both EFL learners and NNESPTs. Students feel less confident, as the expectations are unrealistic. Their inability to speak and pronounce English according to 'native'speakers' norms may indeed result in broader forms of inability or disability. For instance, it may lead to students' reluctance to develop other areas of the language such as syntactic structures. It may also be conducive to what Holliday (2017) calls cultural disbelief in that students lose their voices; that is, selfexpression.

This cultural disbelief is most salient in some students' opinions on NNESPTs' insertion of Arabic words while teaching L2 pronunciation as a limitation. The use of the L1 in L2 classrooms has been widely discussed in mainstream literature, and the L1 has been accepted as part of one's identity and that "there is...no particular reason to ban the use of the L1 in the classroom. On the contrary, the L1 is likely to play a valuable role in the acquisition of English" (Ur, 2012, p. 6), as bilingual teaching - or what Ur (2012) refers to as "functional English-knowing bilingualism" (p. 6) - has been proved to be helpful in EFL contexts (e.g., Forman, 2010). In addition, the L1 made it easier for many students - those with low proficiency levels - to communicate with their NNESPTs. In both the questionnaire and the interviews, students valued their NNESPTs for their familiarity with the L1 and reported this to be a deficit on the part of NESPTs. This result is in line with several assertions and research findings (see, e.g., Braine, 2010; Ma, 2012). This familiarity on the part of NNESPTs makes them more likely than NESPTs to diagnose students' problems and weaknesses and thereby more helpful than NESPTs in overcoming these problems. Also, sharing the L1 with students gives NNESPTs the advantage of referring to students' L1 system to explain certain 'interference' problems that they have.

It is worth noting that the question of 'interference' and 'interlanguage' has been contested, and more and more scholars and researchers are 
rejecting the use of the two terms. Jenkins (2006) summarizes the arguments of scholars such as Selinker (1972) that support the use of the terms as follows:

Any difference between their [learners'] output and standard British or American English are to be regarded as errors caused mainly by L1 interference (or, less pejoratively transfer), while the point at which these socalled errors become fixed within the individual learner's repertoire is attributed to a phenomenon known as fossilization. (p. 167)

Selinker's views have influenced many generations of NNESPTs, so much so that NNESPTs are blamed for errors that students make because they serve as bad models. Levis et al. (2016) write that "there is no convincing evidence for...[the] assertion" that "[i]f the input comes from speakers of a learner's own L1, it may reinforce the kind of errors the learners themselves might be apt to make" (p. 3).

Despite the grim picture that we have painted, responses like those of S22 and S24 provide glimpses of hope and gesture towards seeds of a growing consciousness. The two students seem to reject monocultural ways of thinking about learning English. The very fact that S24 remembers her teacher's account reflects the awareness that this student has attained through her teacher. The student is now aware of the fact that an NEST is an ideological concept that has to do with constructs such as race (whiteness), religion (Christianity), and class (middle or upper). Both students are to varying degrees aware of the racism involved in this ideology. Andrews (2007, p. 146) writes, "The impact of such racism, as experienced by the NNS teacher, is perhaps most evident in employment practices, where an employer's stated preference for a NS teacher of English may often translate into a preference for a white Anglo-Saxon." This racialization process could make most non-white, non-Anglo-Saxon teachers or learners of English think of themselves as being inferior and some aspects pertaining to their acquisition of a foreign language deficient.

In response to such prejudices, we advocate a "pluricentric" approach to teaching L2 pronunciation without romanticising it - as many do-in place of a "monolithic" (Jenkins, 2006, p. 159) and "single monochrome standard form" (Quirk, 1985, as cited in Jenkins, 2006, p. 160), both of which were rightly referred to by Kachru as "deficit linguistics" (1991, cited in Jenkins, 2006, p. 170). We argue that in order to achieve that approach, a certain level of awarenessraising is needed on the part of learners - and maybe teachers as well in the form of future research - to accommodate to the new environment of teaching English in foreign language contexts and more globally. We also encourage attention to the "sociolinguistic reality" - to use Brown's (1995, p. 237) and Jenkins' (2006, p. 173) words - of students so that they can build identities on the basis of the variety of English that they are more likely to be using in their limited contexts, as many will mainly be communicating in English with other 'nonnative' English speakers and very rarely with 'native' English speakers. Brown (1995) clearly argues that identifying an individual with the regional variety s/he speaks may be purposefully maintained by many speakers, and that learners' adherence to 'native'speaker "standards' "ignores the sociolinguistic reality" (p. 237) of those learners. What should be promoted instead is "speakers that may be termed trans-varietal, that is, speakers who may not be easily identified as simply speaking one major variety of English" (Sharifian, 2015, p. 529; italics in original). This can only be achieved by the promotion of "trans-cultural mobility," which necessitates exposure to and interaction with various varieties of English (Sharifian, 2015, p. 529).

\section{CONCLUSION}

This paper has attempted to shed some light on one of the most controversial issues in ELT and Applied Linguistics: professional teacher identities in L2 pronunciation instruction. In this paper, we followed in the footsteps of many researchers and scholars who assert that NESPTs' proclaimed power is a myth in which many EFL students unfortunately believe. We noticed that there was very little awareness of several key issues that have to do with learners' perceptions such as the irrelevance of nativeness to effective teaching; the too much emphasis that is usually placed on 'native'speaker models; the connection between conceptions of model, standard, accent, and identity with the dominant power dynamics in any given context; the notion of overgeneralization when it comes to reflecting on teacher performance; and the discourses of individualism and confidence. All of these issues suggest cultural panic and its attendant voicelessness on the part of EFL learners and NNESPTs.

The prevalence of such discourses should not lead to abandoning them. For instance, students' insistence on achieving a high level of fluency in speaking the language should not be disregarded, because this is a source of motivation that drives them to learn and develop L2 pronunciation. Nevertheless, it is advisable that students, especially prospective English language teachers, be made more aware of recent developments in the use of English in their EFL contexts and the emergence of new varieties of WEs and ELF, and more importantly in light of the findings of second language acquisition research about the unlikelihood of achieving native-speaker-oriented goals. Further, accuracy should not be thought as the opposite of fluency and jettisoned. As part of this process of awareness-raising, a number of myths need to be dispelled. One of these myths is the idea that NNESTs' use of L1 should be discouraged. Another is NESTs' focus on Western values such as individualism, veiled by confidence, which might run counter to students' respective cultures. Most important of all is the myth of native-speakerism as the key to successful teaching and learning. All of these myths suggest one way of looking at the world. 
In contrast, multiple ways of looking at the world require an emphasis on the role of the NNEST in a way that does not contradict current trends to transform education into a learner-centred process. We accordingly suggest that NNESTs be given as many-if not more-opportunities as NESTs, eliminating any NNEST's linguistic panic. This way, they may empower their students to voice themselves and express their own thoughts instead of having to deal with unrealistic goals and inauthentic situations. In other words, their teaching and their students' learning must not be seen as an aspect of deficiency or cultural disbelief, as Holliday (2017) argues. Rather, their learning should mirror one of the most salient features of humanity: our differences and diversity. We should promote the idea that the world is not monochromatic; it is polychromatic.

\section{REFERENCES}

Alghazo, S. (2013). Pronunciation instruction in Jordan: Practices and beliefs (Unpublished doctoral thesis). University of Technology Sydney, Sydney, Australia.

Alghazo, S. (2015). Advanced EFL learners' beliefs about pronunciation teaching. International Education Studies, 8(11), pp. 63-76. doi:10.5539/ies.v8n11p63

Andrews, S. (2007). Language teacher awareness. Cambridge: Cambridge University Press.

Benke, E. \& Medgyes, P. (2005). Differences in teaching behaviour between native and non-native speaker teachers: As seen by the learners. In E. Llurda (Ed.), Non-native language teachers: Perceptions, challenges, and contributions to the profession (pp. 195-215). New York: Springer.

Braine, G. (2010). Nonnative speaker English teachers: Research, pedagogy, and professional growth. New York: Routledge.

Brooks-Lewis, K. (2009). Adult learners' perceptions of the incorporation of their L1 in foreign language teaching and learning. Applied Linguistics, 30(2), 216-235.

Brown, H. D. (2007). Principles of language learning and teaching (5th ed.). New York: Pearson Education.

Brown, K. (1995). World Englishes: To teach or not to teach. World Englishes, 14(2), 233-245.

Buckingham, L. (2014). Attitudes to English teachers' accents in the Gulf. International Journal of Applied Linguistics, 24(1), 50-73.

Chomsky, N. (1965). Aspects of the theory of syntax. Cambridge, MA: MIT Press.

Creswell, J. \& Plano Clark, V. (2007). Designing and conducting mixed methods research. Thousand Oaks, CA: SAGE Publications.

Davies, A. (2003). The native speaker: Myth and reality. Clevedon: Multilingual Matters.

Ellis, R. (2012). Language teaching research and language pedagogy. West Sussex: WileyBlackwell.
Ferguson, C. A. (1971). Absence of copula and the notion of simplicity: A study of normal speech, baby talk, foreigner talk, and pidgins. In D. Hymes (Ed.), Pidginization and creolisation of languages (pp. 141-150). Cambridge: Cambridge University Press.

Forman, R. (2007). Bilingual teaching in the Thai EFL context: One teacher's practice. TESOL in Context, $16,19-24$.

Forman, R. (2010). Ten principles of bilingual pedagogy in EFL. In A. Mahboob (Ed.), The NNEST lens: Non-native English speakers in TESOL (pp. 54-86). Newcastle, UK: Cambridge Scholars Publishing.

Golombek, P. \& Jordan, S. R. (2005). Becoming "black lambs" not "parrots": A poststructuralist orientation to intelligibility and identity. TESOL Quarterly, 39(3), 513-533.

Goodwin, J. (2014). Teaching pronunciation. In M. Celce-Murcia, D. Brinton, and A. Snow (Eds.). Teaching English as a second or foreign language (pp. 136-153). Boston: Cengage/National Geographic Learning.

Holliday, A. (2015). Native-speakerism: taking the concept forward and achieving cultural belief. In A. Swan, P. Aboshiha, \& A. Holliday (Eds.), (En)Countering native-speakerism: Global perspectives (pp. 11-25). London: Palgrave Macmillan.

Holliday, A. (2017). Native-speakerism. In J. Liontas (Ed.), TESOL encyclopedia of English language teaching. Bognor Regis: Wiley.

Jenkins, J. (2006). Current perspectives on teaching World Englishes and English as a lingua franca. TESOL Quarterly, 40(1), 157-181.

Kachru, B. B. (1991). Liberation linguistics and the Quirk concern. English Today, 25, 3-13.

Kachru, B. B. (1997). English as an Asian language. In M. L. S. Bautista (Ed.), English is an Asian language: The Philippine context (pp. 1-23). Sydney: Macquarie Library Pty.

Kamhi-Stein, L., Aagard, A., Ching, A., Paik, M. \& Sasser, L. (2004). Teaching in kindergarten through grade 12 programs: perceptions of native and nonnative English-speaking practitioners. In L. D. Kamhi-Stein (Ed.), Learning and teaching from experience: Perspectives on nonnative Englishspeaking professionals (pp. 81-99). Ann-Arbor: The University of Michigan Press.

Lasagabaster, D. \& Manuel-Sierra, J. (2005). What do students think about the pros and cons of having a native speaker teacher? In E. Llurda (Ed.), Nonnative language teachers: Perceptions, challenges, and contributions to the profession (pp. 217-241). New York: Springer.

Levis, J., Link, S., Sonsaat, S. \& Barriuso, T. (2016). Native and non-native teachers of L2 pronunciation: Effects on learner performance. TESOL Quarterly, 50(4), 894-931. 
Levis, J., Sonsaat, S. \& Link, S. (2017). Students' beliefs about native vs. non-native pronunciation teachers. In J. Martínez Agudo (Ed.), Native and non-native teachers in English language classrooms: Professional challenges and teacher education (pp. 205-237). Berlin: Walter de Gruyter.

Leung, C., Harris, R. \& Rampton, B. (1997). The idealised native speaker, reified ethnicities, and classroom realities. TESOL Quarterly, 31(3), 543560.

Liu, J. (1999). Non-native-English-speaking professionals in TESOL. TESOL Quarterly, 33(1), 85-102.

Mahboob, A. (2003). Status of nonnative English speakers as ESL teachers in the United States (Unpublished doctoral thesis). Indiana University, United States of America.

Mahboob, A. (2004). Native or nonnative: What do students enrolled in an intensive English program think? In L. D. Kamhi-Stein (Ed.), Learning and teaching from experience: Perspectives on nonnative English-speaking professionals (pp. 121-147). Ann-Arbor: The University of Michigan Press.

Ma, L. (2012). Advantages and disadvantages of nativeand nonnative-English-speaking teachers: student perceptions in Hong Kong. TESOL Quarterly, 46(2), 280-305.

Mcneill, A. (2005). Non-native speaker teachers and awareness of lexical difficulty in pedagogical texts. In E. Llurda (Ed.), Non-native language teachers: Perceptions, challenges, and contributions to the profession (pp. 107-128). New York: Springer.

Medgyes, P. (1994). The non-native teacher. London: Macmillan.

Medgyes, P. (2001). When the teacher is a non-native speaker. In M. Celce-Murcia (Ed.), Teaching English as a second or foreign language (pp. 429442). Boston: Heinle \& Heinle.

Moyer, A. (2013). Foreign accent: The phenomenon of non-native speech. Cambridge: Cambridge University Press.

Nunan, D. (2015). Teaching English to speakers of other languages. New York: Routledge.

Quirk, R. (1990). Language varieties and standard language. English Today, 21, 3-10.

Rampton, M. B. H. (1990). Displacing the 'native speaker': Expertise, affiliation and inheritance. ELT Journal, 44(2), 97- 101.

Richards, L. (2005). Handling qualitative data: A practical guide. London: Sage Publications.

Selinker, L. (1972). Interlanguage. International Review of Applied Linguistics, 10, 209-231.

Sharifian, F. (2015). Cultural linguistics and World Englishes. World Englishes, 34(4), 515-532.

Swan, A. (2015). Redefining English language teacher identity. In A. Swan, P. Aboshiha \& A. Holliday (Eds.), (En)countering native-speakerism: Global perspectives (pp. 59-74). Hampshire: Palgrave Macmillan.

Tang, C. (1997). The identity of the nonnative ESL teacher: on the power and status of nonnative ESL teachers. TESOL Quarterly, 31(3), 577-580.

Tatar, S. \& Yildiz, S. (2010). Empowering nonnativeEnglish speaking teachers in the classroom. In A. Mahboob (Ed.), The NNEST lens: Non-native English speakers in TESOL (pp. 114-128). Cambridge Scholars Publishing, Newcastle upon Tyne.

Ur, P. (2012). A course in English language teaching (2nd ed). Cambridge: Cambridge University Press.

Watson-Todd, R. \& Pojanapunya, P. (2009). Implicit attitudes towards native and non-native speaker teachers. System, 37(1), 23-33. 


\section{APPENDIX}

\section{Appendix A}

Student Questionnaire

1. How many pronunciation subjects had you studied before this semester?
[ ] 1
[ ] 2
[ ] 3
[ ] none

2. Have you been taught that/those subject/s by a

[ ] Native English speaking pronunciation teacher

[ ] Non-native English speaking pronunciation teacher

[ ] Both

3. Who do you prefer to learn English pronunciation from?

[ ] Native English speaking pronunciation teacher

[ ] Non-native English speaking pronunciation teacher

[ ] Either

4. Explain your answer to 3 in the space provided.

\section{Appendix B}

Interview Questions and Discussion Topics

1. Given your prior experience learning from 'native' and 'nonnative' English-speaking pronunciation teachers, how did you find this experience?

2. Who did you find to be more effective in teaching, NESPTs or NNESPTs? Why do you think so?

3. What did you like the most about NESPTs?

4. What did you like the most about NNESPTs?

N.B.: The above questions slightly varied from one discussion session to another. 